PALEO

Revue d'archéologie préhistorique

$27 \mid 2016$

Varia

\title{
Rouffignac cave (Dordogne, France): a source of raw material exploited in the Mesolithic
}

Morgane Dachary, Frédéric Plassard and Hélène Valladas

\section{OpenEdition}

1 Journals

Electronic version

URL: http://journals.openedition.org/paleo/3238

DOI: 10.4000/paleo.3238

ISSN: $2101-0420$

Publisher

SAMRA

Printed version

Date of publication: 30 December 2016

Number of pages: 133-148

ISSN: 1145-3370

\section{Electronic reference}

Morgane Dachary, Frédéric Plassard and Hélène Valladas, « Rouffignac cave (Dordogne, France): a source of raw material exploited in the Mesolithic », PALEO [Online], 27 | 2016, Online since 01 June 2018, connection on 07 July 2020. URL : http://journals.openedition.org/paleo/3238 ; DOI : https:// doi.org/10.4000/paleo.3238

This text was automatically generated on 7 July 2020 .

\section{cc) (†) $\ominus$}

PALEO est mis à disposition selon les termes de la licence Creative Commons Attribution - Pas d'Utilisation Commerciale - Pas de Modification 4.0 International. 


\title{
Rouffignac cave (Dordogne, France): a source of raw material exploited in the Mesolithic
}

\author{
Morgane Dachary, Frédéric Plassard and Hélène Valladas
}

Thirteen years have passed since the field operation at the origin of this article. Over time, we have received help from several friends and colleagues: P.-Y. Demars was the first to look at the lithic material; C. Ferrier spent some time validating, on the basis of micromorphological sampling, the presence of the lighting hearth; L. Daulny carried out the analysis of the spatial distribution of the remains; $S$. Thiébault carried out the anthracological determining of the charcoals intended for radiocarbon dating; B. Gravina was kind enough to proofread (and a little more!) the abstract and captions in English. In addition, having presented this study at the round table "From techniques to territories: new perspectives on Mesolithic cultures" in Toulouse in 2012, we were able to benefit from fruitful exchanges with the experts of the Mesolithic period; exchanges that have continued with the reviewers of this article. May they all be sincerely thanked here.The Regional Archaeological Service of Aquitaine financed this operation and the subsequent radiocarbon dating. Thanks to D. Barraud and J.-M. Geneste, then in charge of this file, for their support and trust.

1 The exploitation of siliceous raw materials by prehistoric people has been widely documented for surface deposits at all times in prehistory and by the digging of mines, especially in the Neolithic period. The exploitation of directly accessible flint in natural galleries, excavated in flint limestone, is seldom reported (Gopher and Barkai 2006; Apellaniz and Domingo Mena 1987). Thus the Mesolithic of Rouffignac cave illustrates a rarely documented originality.

Located on a secondary tributary of the right bank of the Vézère river, in the Dordogne, and known above all as a decorated cave, gathering 250 Paleolithic parietal representations (Barrière 1982; Plassard J. 1999; Plassard F. 2005a), Rouffignac cave was also often visited during the Holocene. Cl. Barrière's research has documented Mesolithic settlements at the entrance porch and the late prehistory visiting of the cave for burial activities (Barrière 1973a et b, 1974; Chevillot 1981). The identification of 
knapped flint in the deep part of the cave goes back to the first archaeological surveys in the summer of 1956 (Nougier and Robert 1957 - p. 99). Later, Cl. Barrière pointed out "flintknapping workshops" at several places in the cave and attributed them to the Mesolithic, connecting them with the settlements unearthed at the entrance porch. However, he did not carry out any detailed study of these remains. More recently, as part of a systematic survey of the floors of the decorated galleries aiming at exposing portable remains related to the passage(s) of the Paleolithic artists (Plassard 2005a and b), we investigated a small knapping cluster situated at the foot of a decorated wall.

3 The collected material contains more than 1,200 remains, of which $95 \%$ flint that were submitted to a techno-typological study. Radiocarbon dating on wood charcoal also makes it possible to restore the material in the chronological context of the entrance porch settlements. This series also raises the question of the activities carried out onsite in a relatively hostile environment where the management of lighting, and more generally logistics, take a special place. In addition to knapping, are the collected remains documenting other activities, as is often the case at workshop sites unearthed and excavated in the open? From another point of view, this study leads to a reassessment of the archaeological potential of the Rouffignac galleries floors, long underestimated because of the historical visiting of the cave network.

\section{1 - Presentation of the study area}

4 The karst network of Rouffignac, dug for the most part in flint limestone of the upper Santonian (Platel 1999), offers about eight kilometers of galleries spread over three levels. Except for two passages of the lower levels, only the upper level is of archaeological interest. Totally fossil, it is made up of rather large galleries where countless flint nodules are showing. These are also abundant in the clayey fill that partially plugs the corridors.

5 Situated about $800 \mathrm{~m}$ from the entrance, the excavated area is located in the deep part of the Henri Breuil gallery, in a sector untouched by the tourist facilities (fig.1a). After a zone whose floor is much disturbed by bear nests, and a sinkhole towards the lower levels, a more regular ground area develops on about ten meters in length. At this point, the gallery is 5 to $6 \mathrm{~m}$ wide and $2.20 \mathrm{~m}$ to $2.50 \mathrm{~m}$ high (fig. $1 \mathrm{~b}$ ).

6 At the base of the left wall, a Paleolithic artist engraved a mammoth silhouette (no. 225 of Cl. Barrière's inventory in 1982). It is immediately at the foot of this representation that a small cluster of flakes and flint nodules was found with some wood charcoals. Several dozens of remains were directly visible on the ground on a surface hardly more than one square meter large (fig 1c). 
Figure 1 - a-Plan of Rouffignac cave and location of the study area. b- General view of the gallery with study area indicated on the left. c- The knapping cluster at the base of the decorated wall before the excavation.

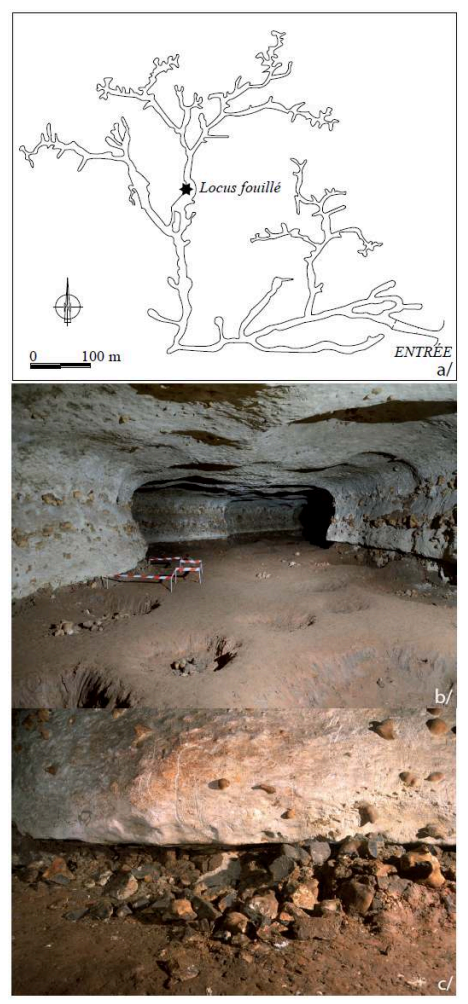

\section{2 - Sedimentary and taphonomic context, sampling method}

7 The sedimentary and taphonomic context of this study area, and more generally of the remains that can be identified at Rouffignac (except in the porch area), is marked by a near absence of sedimentation. Indeed, we are facing only two types of soil, both fossil: areas of large rock falls, probably older than the first human visits, and clay soils dug with nests by bears that had abandoned the cave long before the coming of the Paleolithic artists. Consequently, the archaeological remains are found only on the surface and outside any stratigraphy. Moreover, the complex history of the cave, which has been constantly visited for millennia, makes us wonder about the degree of disturbance of the assemblages of remains, knowing that the anthropogenic factor is in this case the most important.

All these observations led us to adapt the sampling methods to this original context. If such conditions facilitate prospecting, they require to qualify the notion of excavation. In situ interventions essentially involve direct sampling of the material, sometimes after very slightly exposing the surface. Besides, during the field operation, it appeared that if the larger objects were mobile enough, and it was therefore difficult to assert that they were in primary position, on the other hand, the smallest objects, pushed a few millimeters into the very compact clay of the soil, were unlikely to have moved much. It is for this reason that we tried to record all the remains, without any size limit. The low volume of sediment collected and isolated per quarter of square meter 
was nevertheless water-sieved and all the sieving residues were retained and sorted. Splinters caught into the clay stuck on the recorded objects appeared during the washing of the material and were also kept.

9 The surface excavation only cut into the sediment on one to two centimeters deep. However, a deeper test (six centimeters) carried out on a quarter of a square meter showed that the underlying clay was totally sterile.

\section{3 - The archaeological remains}

\section{1 - General presentation}

10 The collected material is distributed unevenly between lithic remains, charcoals and bone splinters. Quantitatively, the lithic industry dominates largely $(1,184$ recorded objects, that is to say $95 \%$ of the collected remains), whereas only 50 charcoals were collected and there are only six bone splinters, all indeterminate, whose alteration suggests that they are related to the passage of cave bears and not with that of Humans.

11 The excavated surface is fairly regular, although it is slightly sloping towards the axis of the gallery. There are also three limited irregularities (fig. 2). A desiccation crack crosses obliquely the A2, B2 and B1 squares. It is mostly visible in A2, where it may have been increased by the extraction of a nodule caught into the clay. The other two are the shallow depressions (about ten centimeters maximum) that affect the B2 and C2 squares. The latter is outside the excavated area, but the large artefacts gathered in the small basin have been removed without recording and integrated into the study of the material. The bottom of the B2 depression was found to be poor in flint, but indurated and rich in charcoals. A micromorphological sample allowed making a thin plate that shows traces of rubefaction (C. Ferrier, in verbis). A small lighting hearth was undoubtedly lit in this probably natural depression. 
Figure 2 - General view of the study area before excavation.

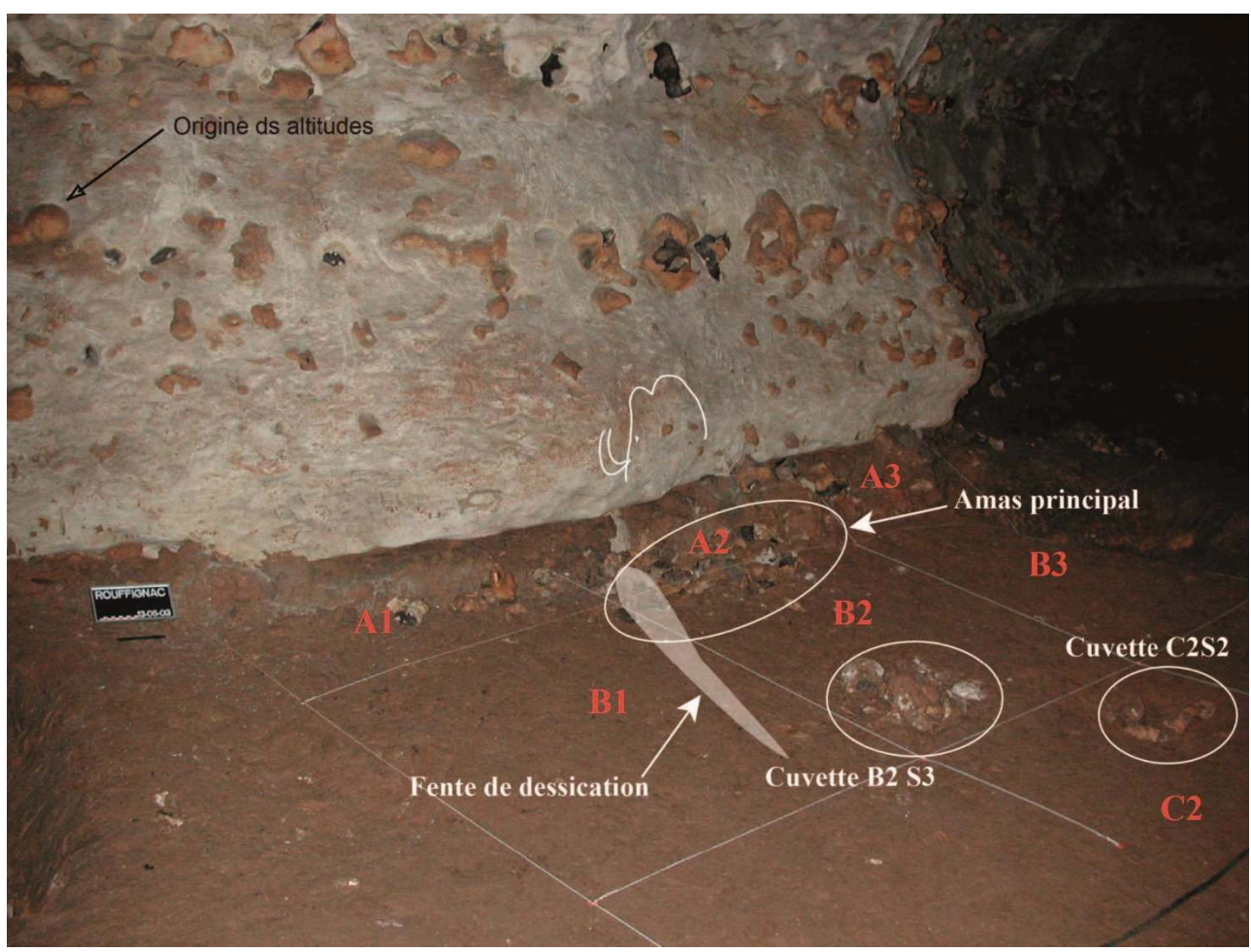

12 This description makes it easy to understand that the study of the lithic remains collected constitutes the essential source of information to answer the questions raised.

\section{2 - Technological study of the lithic material}

\subsection{1 - Methodology}

13 The methodology implemented was organized around two points: an in-depth technological analysis and the search for physical refittings, within the entire series collected in the excavation but also with the fractured nodules on the rock walls.

14 The technological study was accompanied by a systematic observation of certain descriptive elements, facilitating the diagnosis of the percussion technique: butt presence/absence, butt nature, bulb scar presence/absence, knapping accident or marked ripples on the lower face.

\subsection{2 - General characteristics of the series}

15 The pieces recorded during the excavation are essentially flakes (43.9\%) then splinters (25.8\%) and technically non-characteristic fragments (19.7\%). The latter two categories (that is to say $45.5 \%$ of the remains) lack the technical marks that would make it possible to reproduce them in an operative scheme. This absence is explained either by the very small dimension of the objects or by the abundance of the natural fractures shown by the fragmentation of the block.

16 The remaining $10 \%$ of the material is distributed, in decreasing order of size, between bulb scars (whole or fragmentary: 4.4\%), more or less fragmentary nodules (3.6\%), butt 
preparation flakes $(0.7 \%)$ and elongated flakes $(0.7 \%)$. Bladelet cores rough-outs, core preparation flakes on flake slice and bladelets are very rare.

In all categories combined, the cortex rate is generally less than $15 \%$, even if the objects covered with $80 \%$ or more cortex make a non-negligible part of the series.

In detail, for objects with a maximum dimension equal to or under $1 \mathrm{~cm}$, the cortex rate is less than $15 \%$ in $80 \%$ of the cases, while the percentage is $50 \%$ for objects larger than $1 \mathrm{~cm}$. Similarly, a cortex rate greater than or equal to $80 \%$ concerns $28 \%$ of the objects of more than $1 \mathrm{~cm}$ compared to just $10 \%$ of the pieces of dimension less than or equal to $1 \mathrm{~cm}$.

19 Finally, among the flakes, whatever their size, $63.2 \%$ are covered with less than $25 \%$ cortex, $14 \%$ are semi-cortical and $22.8 \%$ are cortical.

\subsection{3 - Analysis of percussion marks}

Plunging and Siret fractures concern only the flakes: 13 objects in the first case, 49 in the second. $15.1 \%$ of the flakes are hinged ( 81 objects, as well as one Kombewa flake and one bladelet). Finally, only two pieces have a careful preparation of the butt: a flake and the only bending flake described.

Opening flakes (cortical or semi-cortical) are often either clearly hinged or with two or three series of marked ripples at the distal end.

Note the abundance of micro-splinters in the form of very small sticks (no more than $2.5 \mathrm{~mm}$ in length). Their presence is the consequence of the high joint cracking of the raw material and not the sign of opening the blocks by bipolar percussion on anvil. Indeed, on the one hand, the pieces with violent percussion scars show that these negatives are always oriented in the same direction and never in opposition and, on the other hand, some heavily jointed nodules literally explode at the opening, provoking the release of a multitude of splinters (fig. 3a).

The abundance of micro-splinters may also be the consequence of the irregularity of the raw material as well as of the strength necessary to get through a subcortical zone, sometimes very soft, up to $2 \mathrm{~cm}$ thick. Given the context in which the cave was visited, the mode of percussion must be carefully discussed, especially as it may constitute a dating element if it is metal or punch percussion. The scarcity of the lips under the butt, the abundance of Siret accidents (9.2\% of the flakes), of hinging (15.1\% of the flakes), flat and wide butts (only one is concave), bulb scars and/or marked ripples on the lower face make us lean towards a perpendicular debitage with hard hammerstone.

At the same time, the incipient cones can be cut out on nearly half their size. They have highly variable dimensions: from 1-2 $\mathrm{mm}$ to $6-7 \mathrm{~mm}$. One object (A1\#22, fig. $3 \mathrm{~b}$ ) shows that the hammerstone got crushed at the time of impact, causing three concentric and overlapping cones to form.

The excavation did not make it possible to collect hammerstones: no trace of use as a hammer was visible on flint nodules (no scarring on the surfaces) and no pebble was discovered. 
Figure 3: a- B1\#53. Two roughing-out flakes. Surface management of heavily jointed nodule- C2\#5. b- A1\#22, cortical flake. Butt, top right: natural (joint) surface with concentric cracks (Three overlapping incipient cones).

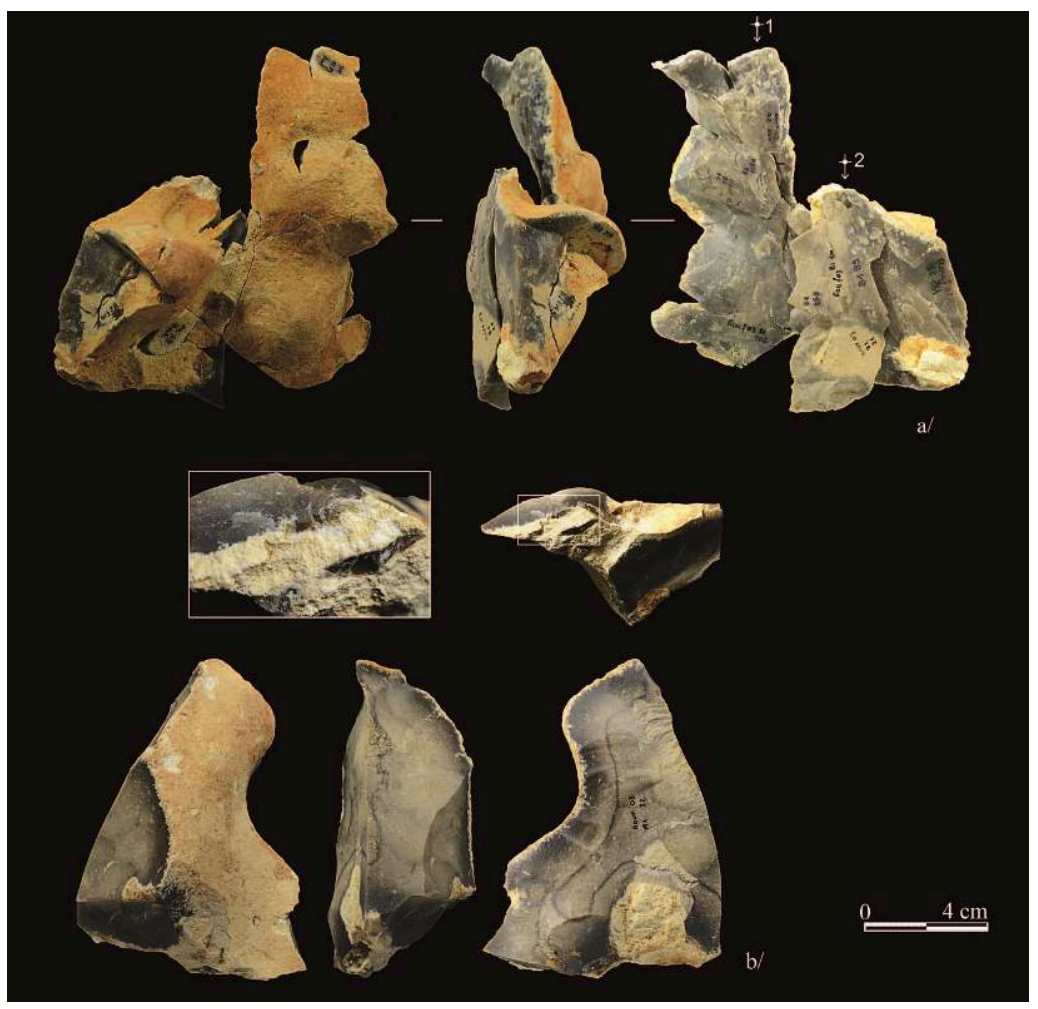

\subsection{4 - Toolkit}

There are no tools in this series. The only marks of splintering on the cutting edges correspond to chipping at the time of debitage.

\subsection{5 - Refitting}

Of the 902 recorded objects larger than or equal to $1 \mathrm{~cm}, 207$ could be refitted $(22.9 \%$ refitting rate). It should be added that 12 pieces under $1 \mathrm{~cm}$ in maximal dimension were attached to these same refittings.

The analysis of the physical refittings carried out leads to the formalization of a raw material exploitation scheme (fig. 4), indicating that the samples were taken by fracturing the nodules on the walls or by collecting (and extracting?) on the floor. A diagnosis of the quality of the raw material by testing was then carried out. 
Figure 4 - Chaîne opératoire of flint reduction.

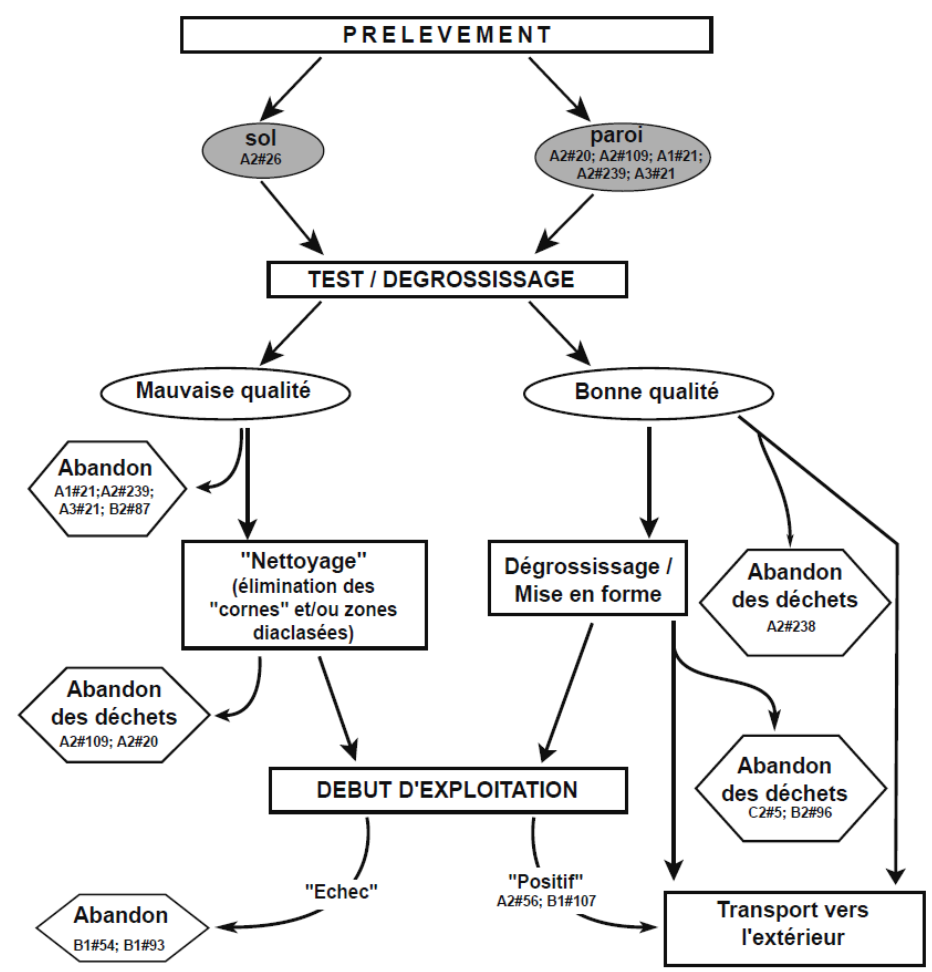

If the raw material was of very good quality, the nodule was then transported outside of the studied area after abandoning isolated pieces (A2\#238, fig. 5c) or pieces showing short sequences of debitage. Roughing-out, possibly followed by an initial exploitation, could also be undertaken on site. It resulted in the abandonment of the outer shell of the block (A2\#56, fig. 6, B2\#96, fig. 5d and C2\#5, fig. 5a), and sometimes of the shaping flakes of the convexities of the core (A2\#56 and B1\#107, fig. 7a).

The poor quality of the raw material is visible in the absence of internal silicification, in significant natural cracking, or by the presence of non-exploitable zones ("horn", thick cortex, jointed zones, etc.). In the first two cases, the tests are pushed to a greater or lesser extent (A1\#21, A2\#26, fig. 8b, A2\#239, fig. 8d, A3\#21, B2\#87, fig. 8c and A2\#233, fig. $8 \mathrm{a})$ and lead to the abandonment of all products on-site. In the latter case, preparation was undertaken, leading to the abandonment of the non-exploitable areas (A2\#109; A2\#20, fig.8e). Exploitation can then be undertaken successfully or not (B1\#54; B1\#93).

Attempts of connecting the refittings done in the laboratory and the larger objects collected during the excavation to the nodules on the walls were tried. Each refit was tested on the negatives visible on the two walls of the gallery about fifteen meters on each side of the excavated area.

Six objects, or groups of objects, could be connected to the wall. In all cases, they are located in the area immediately above the excavation area. From left to right, these are:

1. A1\#21, a nodule "branch" whose opposite end has not been percussed;

2. A2\#109 and refitting A2\#20. After removing of the "horn" A2\#109, the knapper continued the test by removing the remains refitted around $A 2 \# 20$;

3. A2\#239, on the same nodule, but on the "branch" to the far right. The extremity opposite to the wall was not percussed; 
4. above, refitting A2\#233 that connects to the wall by A2\#234. It is a nodule with a "horn", tested, but of poor quality;

5. finally, at the extreme right of the wall: A3\#21, a "branch" of nodule whose opposite end was not percussed. that are bulb scars or flank flakes). 
Figure 5 - a- C2\#5. Series of 3 roughing-out flakes; Fine-grained waxy flint. b- B1\#59. Series of 3 roughing-out/cintrage flakes on a blade core (note the preparation of the butt). The third flake has crushed butt. c-A2\#238. Cortical flake. d- B2\#96. 2 roughing-out flakes. Fine-grained waxy flint.

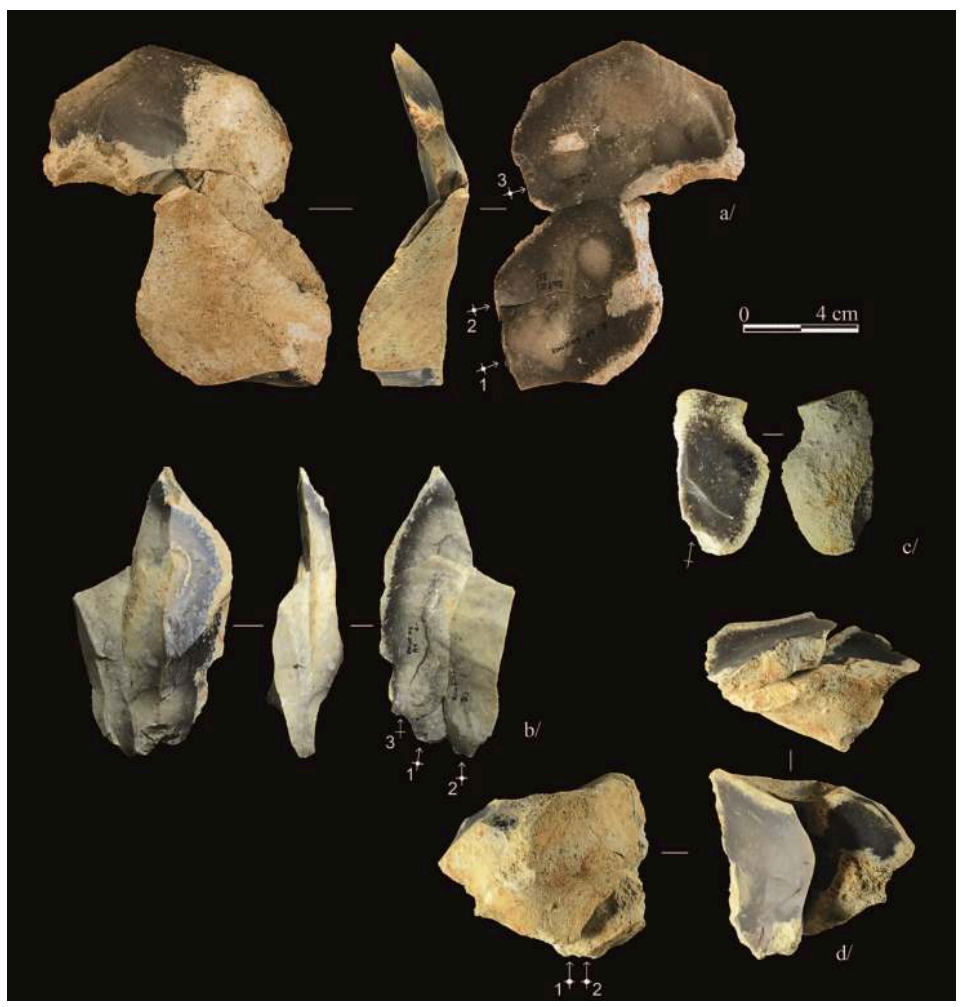

Figure 6 - A2\#56. Roughing-out of a blade core and beginning of reduction (not visible in the photo).

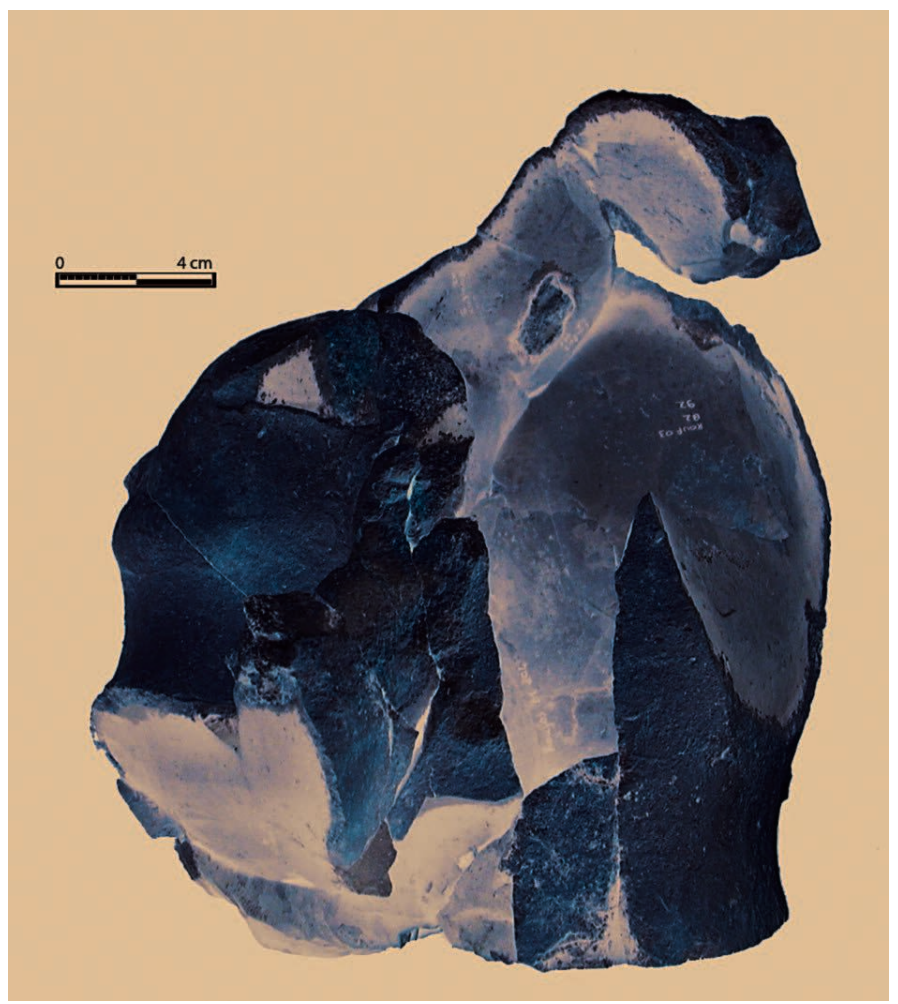


Figure 7 - Example of blade and bladelet production.

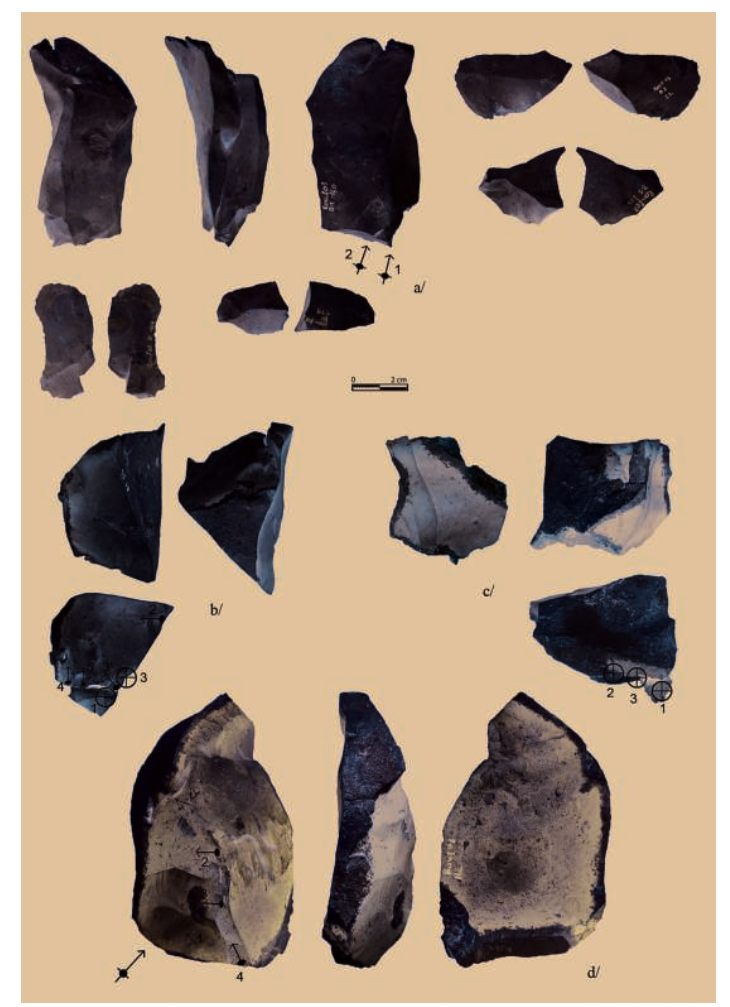

a- Flakes and refit B1\#107: preforming and beginning of blade production. b- A1\#38: bladelet core; production of semi-cortical bladelet (1), followed by the preparation of a new striking platform $(2,3$ ', 4 and 5). c- B1\#93: bladelet core, waxy flint. Description of the refitting: Elongated flake (1) is removed, then a second elongated flake (2) is removed (only the distal portion was recovered) and a bladelet, is removed, also not recovered. The striking platform is a natural surface. $d$ - A2\#22: roughing out of a bladelet core, waxy flint. Preparation of a central crest $(1,1,2$ and 3$)$ then production of a bladelet that was not recovered (4).

\subsection{6 - Conclusions}

If refittings demonstrate that some of the knapped nodules could have been taken from the wall, other blocks had to be collected from the floor or extracted from the clay fill. This latter case is no doubt illustrated by the large widening in square A2 of the crack that intersects the excavated area. Let us also emphasize that the refittings with wall negatives were positive only immediately above the excavated area, whereas they were attempted on both walls of the gallery and on about thirty meters long.

This highly homogeneous assemblage in its management and percussion modes shows that the activities carried out on site are exclusively knapping. The total absence of tools, already visible during the excavation, is confirmed. Not only the "classical" toolkit, visible through its more or less abrupt retouching, does not exist in the series, but none of the objects were used nor crushed. The only signs of wear or "retouching" are related to knapping accidents (see for example A2\#37). Note also the absence of hammerstone, in non-local rock or flint nodule. Indeed, none of them carries any marks resulting of this use.

The systematic study of this material demonstrates the presence on-site of the first three steps of the raw material reduction chaine opératoire: the testing of the blocks, the roughing-out and the start of a production on-site (bladelets in particular) recognizable 
by the care taken in the preparation of the butts. They also refer to several behaviors related to both the quality of the raw material and the aims of the knapper(s). Thus, we have found some blocks tested and abandoned because of bad quality; some blocks tested and carried away (only scattered flakes remain that often reflect the good quality of the material); some blocks tested, roughly prepared then carried away (we then have series of cortical flakes forming the external shell of the nodule); finally, some blocks tested, roughly prepared and then knapped on-site. Although this situation is only poorly documented in the material, it reflects a behavior that is difficult to understand in an uncomfortable, even hostile environment compared to the entrance porch bathed in daylight.

Figure 8 - Examples of tested blocks.

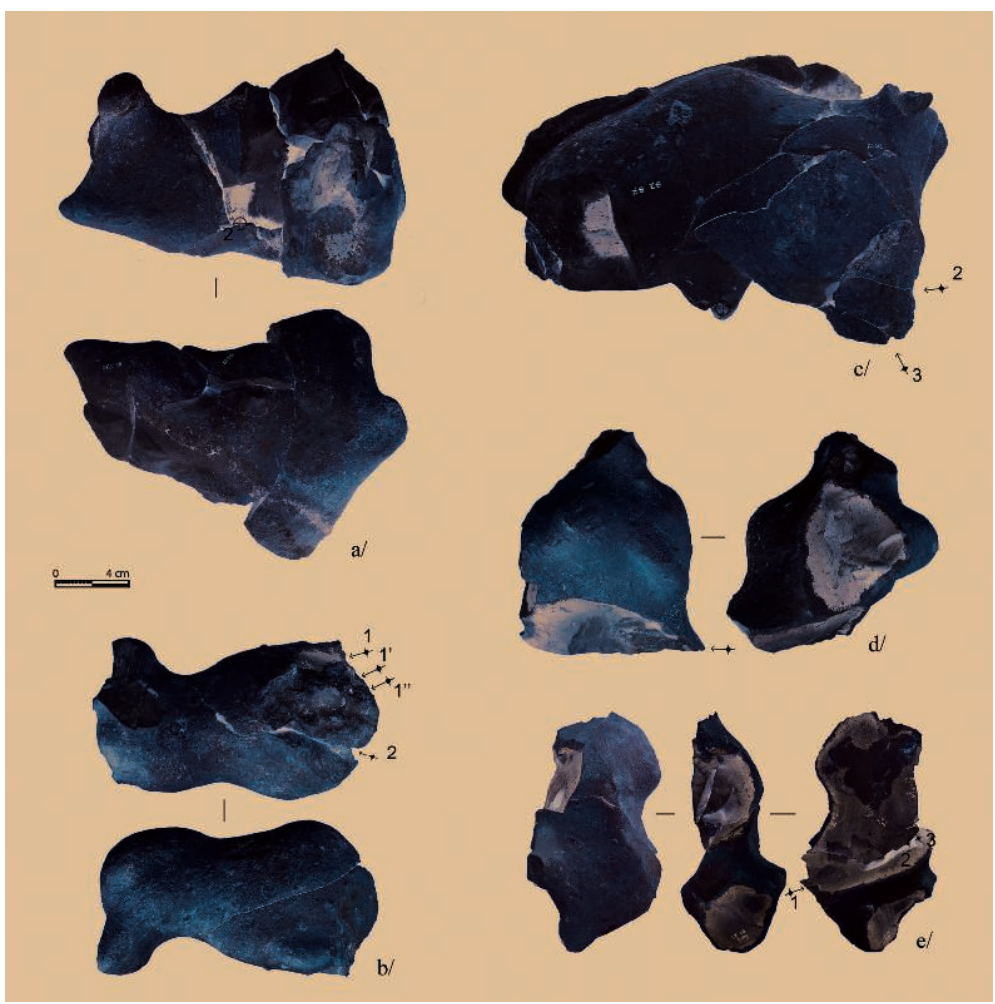

a- A2\#233: 2 impact areas. b- A2\#26: 2 impact areas. c- B2\#87: 3 impact areas. The directions 2 and 3 (perpendicular) are used alternately. d-A2\#239: 1 impact area. e- A2\#20: refitting of 3 flakes (1 with Siret fracture).

\section{4 - Spatial distribution of the remains}

Let us recall that the studied area is reduced in size (about $3 \mathrm{~m}^{2}$ ) with respect to the galleries of Rouffignac. In this context, the study of the spatial distribution of the remains should only be seen as a sample.

41 However, the reading of figure 9 brings on some comments. The first one relates to the density of the remains from one sub-square to the other. The large elements are grouped at the bottom of the B2S3 basin (by gravity) and along the wall (including under the projection it forms near the ground). However, their position is of little significance because they may have been displaced over time, due to the old and 
repeated visiting of the galleries. On the contrary, small elements are absent from B2S3 (a natural basin, the bottom of which is indurated by rubefaction) in which a lighting hearth was probably set up. These same small elements are very numerous in B1S4, and near the wall in A2S4. Finally, the density of remains is low in B1S2 and B2S2/B3S1.

From another point of view, figure 9a shows the distribution of remains involved in the refitting of block B2\#87 (very thorough testing of a bad quality nodule of which all products were abandoned on site). It shows that the concerned remains have not been subjected to significant moving in the axis of the gallery, but rather transversely. This statement is substantially the same for the refitting A2\#56 (fig. 9b).

Figure 9 - Spatial distribution of piece-plotted artefacts.

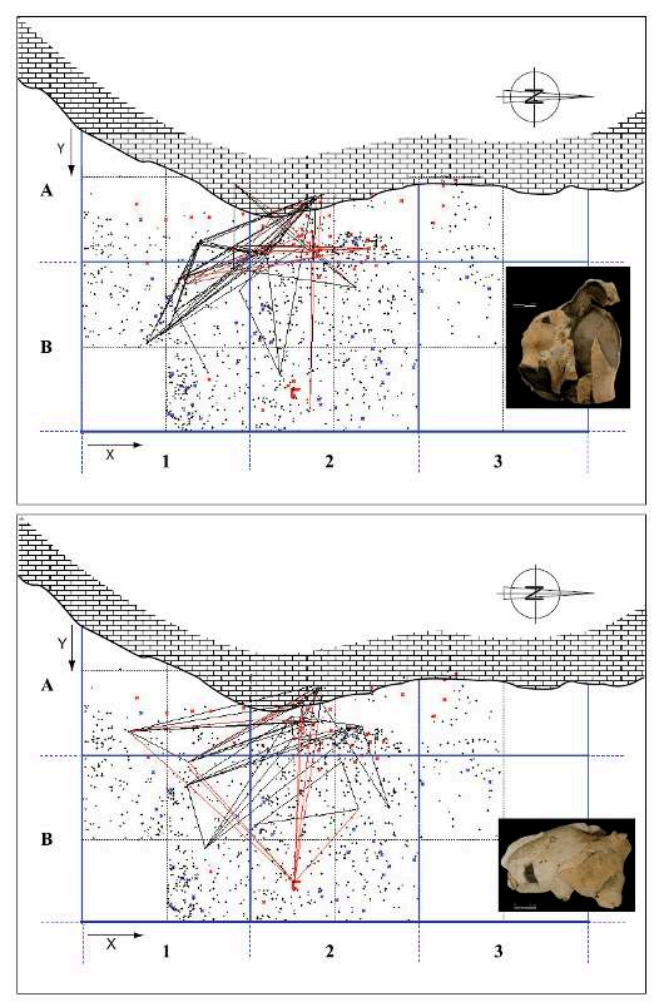

In red, artefacts greater than $5 \mathrm{~cm}$. In blue, artefacts smaller than $1 \mathrm{~cm}$. In black, remaining pieces. aRefit A2\#86. b- Refit B2\#87.

(Projection: L. Daulny)

\section{5 - Radiocarbon dating}

About fifty charcoals were sampled. They are of two very different types. The first ones have the appearance of twigs or straws and appeared on top of the lithic remains. The second ones are massive and were rather concentrated in the shallow basin of square B2, sector 3. The anthracological analysis of the dated samples, carried out by St. Thiébault, shows that the twigs belong to a Rosaceae while the more massive charcoals correspond to hazel tree. The presence of these two types of samples led to carry out two AMS radiocarbon dates at the Laboratory of Climate and Environmental Sciences. Analyzes done on Artemis (LMC14-Saclay) document two distinct visiting of the cave. The Rosaceae ( $\mathrm{A} 1 \mathrm{~N}^{\circ} 30$, GifA 70008/SacA6412) is dated to 2,800 \pm 35 years BP that, when 
calibrated, gives the interval 1,043-846 years cal BC (95.4\% confidence level). As for the hazel charcoal (B2 No. 312, GifA 70007/SacA6411), several millennia older, it is dated to $8,530 \pm 50$ years BP, which corresponds to the calibrated interval 7,608-7,505 cal BC (Bronk Ramsey 2013; Reimer et al. 2013).

\section{6 - Interpretations}

The first of the resulting two dates (1,043-846 years cal BC) refers to the end of the Bronze Age. This result is consistent with the presence of ash deposits associated with ceramic remains classically attributed to the final Bronze Age (Barrière 1974a and b; Chevillot 1981) near the excavated area. However, the absence of metallic percussion traces, the position of the dated twig (above the lithic remains) and the sepulchral purpose of the Late Prehistory visiting of the cave do not encourage us to connect the flint exploitation to the Metal Ages.

The second dated sample, for its part, yields a result $(7,608-7,505$ years cal BC) that is easy to connect with the Mesolithic occupations of the porch. Between 1957 and 1962, a significant sequence (layers 5 to 2 , and their subdivisions), was discovered there by $\mathrm{Cl}$. Barrière. It documents occupations that were then called Sauveterrian and Tardenoisian (table 1), attributed to the first and the second Mesolithic (Barrière 1973a and $b$ ). Layer 4 gave radiocarbon dates equivalent to those of the area studied here (fig. 10). The hypothesis of an exploitation of the siliceous raw material of the cave during the first Mesolithic period is thus supported, especially since the cortex visible on numerous objects of layer 4 have the same characteristics as the nodules of the excavated area.

Tableau 1 - Radiocarbon dating of the Mesolithic occupations of Rouffignac (after Barrière 1973b for the levels at the entrance). The C-14 dates are calibrated using IntCal 2013. (Reimer et al. 2013) and the software OxCal v.4.2 (Bronk Ramsey 2013). The Calibrated intervals are given with a confidence level of $95.4 \%$.

\begin{tabular}{|c|c|c|c|c|c|}
\hline Stratigraphie & Attribution & Ref. Labo & Matériaux/ méthode & Âge BP & $\begin{array}{c}\text { Âge cal BC } \\
\text { à } 95,4 \% \text { de chance }\end{array}$ \\
\hline Couche 2 & \multirow{2}{*}{$\begin{array}{c}\text { Second } \\
\text { Mésolithique }\end{array}$} & GrN-5512 & Charbon / comptage & $6400 \pm 40$ & $5471-5317$ \\
\hline Couche 3 & & Gro-2889 & Charbon / comptage & $7800 \pm 50$ & $6767-6496$ \\
\hline Couche 4 a & \multirow{6}{*}{$\begin{array}{c}\text { Premier } \\
\text { Mésolithique }\end{array}$} & Gro-2913 & Charbon / comptage & $8370 \pm 100$ & $7589-7145$ \\
\hline Couche $4 \mathrm{~b}$ & & Gro-2895 & Charbon / comptage & $8590 \pm 95$ & $7940-7484$ \\
\hline Couche $4 \mathrm{c}$ & & Gro-2880 & Charbon / comptage & $8995 \pm 105$ & $8451-7795$ \\
\hline Couche 5 a & & GrN-5513 & Charbon / comptage & $8750 \pm 75$ & $8187-7596$ \\
\hline Couche $5 \mathrm{~b}$ & & GrN-5514 & Charbon / comptage & $9150 \pm 90$ & $8611-8236$ \\
\hline Atelier (B2\#312) & & GifA 70007 & Charbon / AMS & $8530 \pm 50$ & $7608-7505$ \\
\hline
\end{tabular}


Figure 10 - Radiocarbon dating of the Mesolithic samples of Rouffignac (tabl. 1) are calibrated using IntCal 2013 . (Reimer et al. 2013) and the software OxCal v.4.2 (Bronk Ramsey 2013). Calibrated results are given at 2 sigma ( $95.4 \%$ of confidence level). The date obtained on the charcoal from the study area is consistent with those from layers 4.

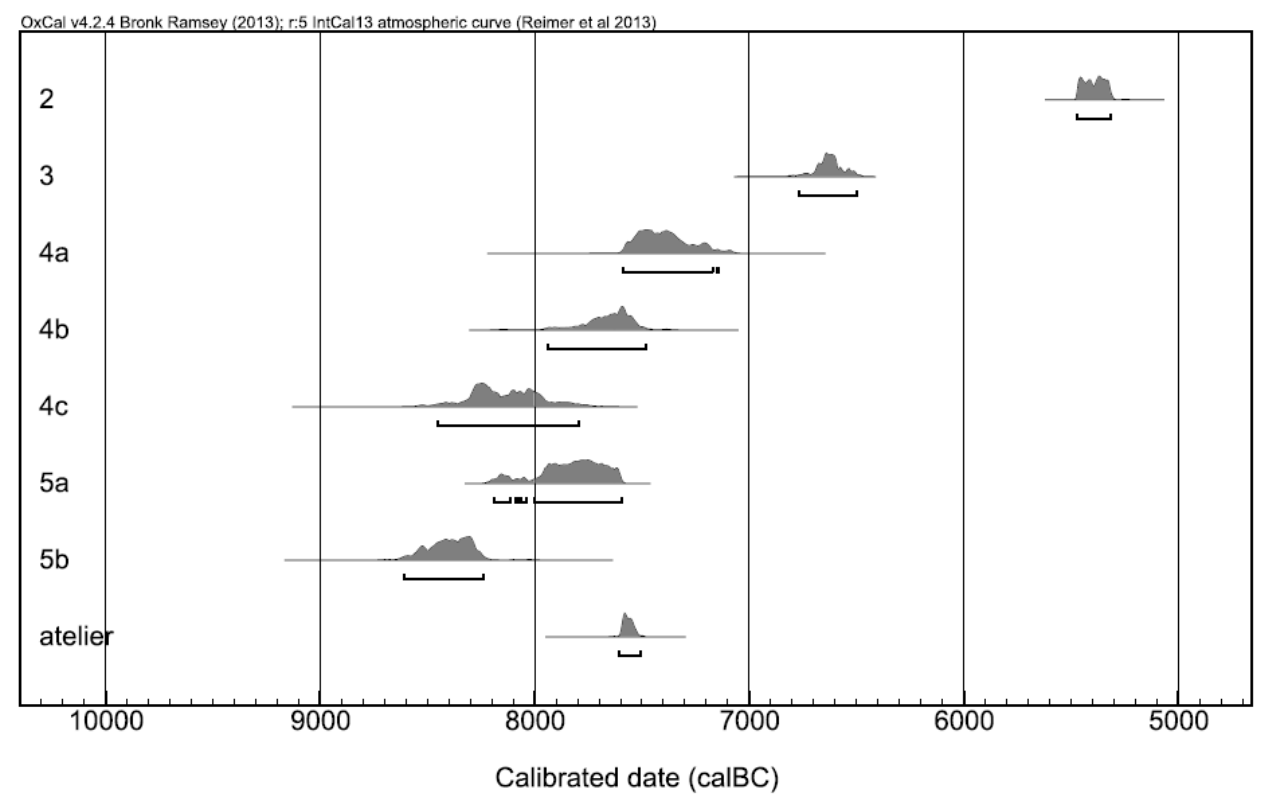

The use of hard percussion during the testing and roughing-out phases of the materials is a ubiquitous technical choice that cannot be used as a chronological evidence. On the other hand, the relative care taken in preparing the butt, the robustness of the laminar blanks, and the highly probable use of hard mineral percussion during the production phases agree better with the first Mesolithic than with the late Magdalenian or the second Mesolithic.

Let us recall here that the studied surface is small in relation to the extent of the cave. It is also small with regard to the likely extension of the areas that have preserved traces of flint exploitation. These appear to be very numerous beyond the studied area, in galleries $\mathrm{H}$ and $\mathrm{I}$, as well as beyond the Great Ceiling. In the latter case, a low gallery (about $1 \mathrm{~m}$ high) preserves several small clusters $\left(1 \mathrm{~m}^{2}\right.$ each) and locally shows layers of obviously less well-preserved remains (fig. 11). In total, several hundred square meters of floors could, with varying degrees of preservation, document the exploitation of the flints of the cave.

At the scale of the site, our study shows that flint exploitation in the cave, although considered by $\mathrm{Cl}$. Barrière, has so far been largely underestimated. But this observation leads to another remark. For many authors, one of the characteristics of the Mesolithic lithic assemblages of Rouffignac is the low rate of microliths. The sampling methods alone cannot explain this fact. On the other hand, the presence of abundant and available raw material probably explains the abundance of the debitage products. It would, however, be unreasonable to reinterpret the occupations of the porch by insinuating that this raw material alone explains the settlement of Men there. The wealth of archaeological objects, comprising all categories of remains, including bone industry and portable art (Marquebielle 2014), shows that the porch of Rouffignac was not a specialized site dedicated solely to flint exploitation. Another lesson at the scale of the site is the need for a reassessment of the archaeological potential of the floors of the Rouffignac galleries, too long considered 
too disturbed by historical frequentations to have a real interest. Although the reading of archaeological evidence is difficult, and their chronological attribution is often debatable, it is clearly exaggerated to abandon any hope of locally discovering exploitable documents relating to such or such prehistoric frequentation of the cave.

An essential chrono-cultural sequence of the Mesolithic of Aquitaine (Rozoy 1978; Valdeyron 1994; Roussot-Larroque 2009), Rouffignac now also testifies to an unprecedented economic behavior. Priority exploitation of local raw materials is favored during this period (Eriksen and Fisher 2002), but it takes on a particular dimension here, since it extends to a natural but a priori hostile environment: deep natural galleries. These, however, do not seem to have received any other activities than those described here. The constraints of the environment have obviously led to a much greater specialization of the activity area than in the open-air workshop sites.

Figure 11-a- Location of the knapping clusters mentioned in the text (not exhaustive map). $b$ - and $\mathrm{c}$ - knapping cluster in a low gallery beyond the Great Ceiling (maximum height : $1 \mathrm{~m}$ ).

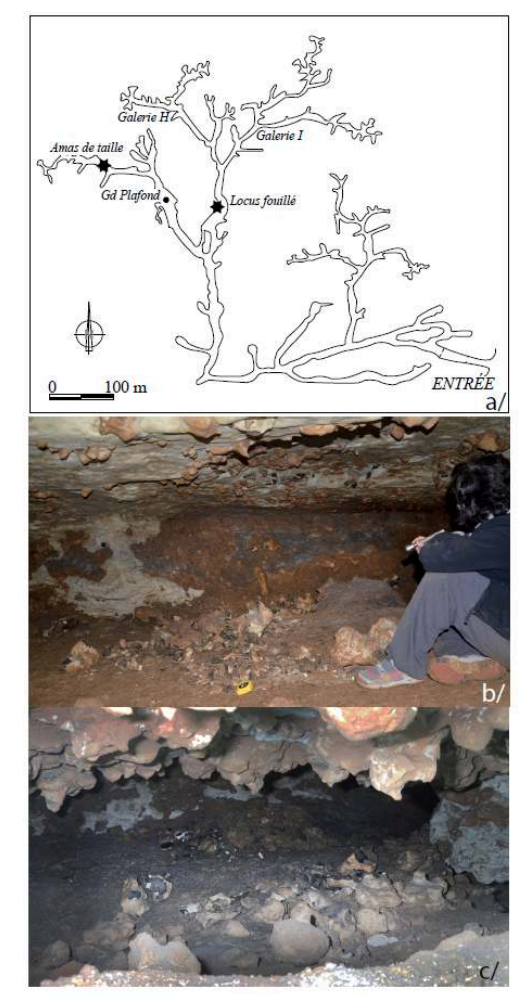

\section{BIBLIOGRAPHY}




\section{References}

APELLANIZ J.-M., DOMINGO MENA 1987 - Estudio sobre Atapuerca (Burgos). II-Los materiales de superficie del sanctuario de la galeria del silex. Estudios de arqueologia de Deusto, $342 \mathrm{p}$.

BARRIÈRE Cl. 1973a - Rouffignac, l'archéologie. Mémoire de l'Institut d'art préhistorique II, fascicule 1. Publication de l'Institut d'art préhistorique de l'université Toulouse-Le-Mirail, $160 \mathrm{p}$.

BARRIÈRE Cl. 1973b - Rouffignac, l'archéologie. Mémoire de l'Institut d'art préhistorique II, fascicule 2. Publication de l'Institut d'art préhistorique de l'université Toulouse-Le-Mirail, $210 \mathrm{p}$.

BARRIÈRE Cl. 1974 Rouffignac, l'archéologie. Mémoire de l'Institut d'art préhistorique II, fascicule 3. Publication de l'Institut d'art préhistorique de l'université Toulouse-Le-Mirail, 83 p.

BARRIÈRE Cl. 1982 - L'art pariétal de Rouffignac, Picard, 208 p.

BRONK RAMSEY C., SCOTT M., van der PLICHT J., “Calibration for archaeological and Environmental Terrestrial Samples in the Time Range 26-50 ka cal BP”. Radiocarbon 55(4), 2013, p. 2021-2027.

CHEVILLOT Ch. 1981 - La civilisation de la fin de l'Age du Bronze en Périgord, Archéologie, recherche et civilisation. $221 \mathrm{p}$.

ERIKSEN B. V., FISHER L. E. 2002 - Lithic raw material economy in Late Glacial and Early Postglacial western Europe : Introduction. In: Fisher et Eriksen B. V. (eds) : Lithic raw material economies in Late Glacial and Early Postglacial Europe. BAR International series 1093, p. 1-5.

GOPHER A., BARKAI R. 2006 - Flint Extraction Sites and Workshops in Prehistoric Galilee, Israel. In : Gabriel Körlin, Gerd Weisgerber (dir) Stone Age - Mining Age - Der Anschnitt, Beiheft 19, p. 91-98.

MARQUEBIELLE B. 2014 - Le travail des matières osseuses au Mésolithique : caractérisation technique et économique à partir des séries du Sud et de l'Est de la France. Thèse de Doctorat de l'Uuniversité de Toulouse-II-Le-Mirail, 508 p.

NOUGIER L.-R., ROBERT R. 1957 - Rouffignac ou la Guerre des mammouths, Paris, Editions de La Table Ronde 311p.

PLASSARD F. 2005a - Les grottes ornées de Combarelles, Font-de-Gaume, Bernifal et Rouffignac. Contexte archéologique, thèmes et style des représentations. Thèse de l'université Bordeaux 1. 413 p.

PLASSARD F. 2005b - Grotte de Rouffignac. Fouille au pied d'une paroi ornée. Bilan scientifique 2003 du Service Régional de l'Archéologie Aquitaine, p. 36.

PLASSARD J. 1999 - Rouffignac, le sanctuaire des mammouths. Paris, Le seuil. 96 p., 96 fig.

PLATEL J.-P. 1999 - Thenon. Carte Géologique de la France à 1/50 000. Éditions du BRGM.

REIMER P. J., BARD E., BAYLISS A., BECK J. W., BLACKWELL P. G., BRONK RAMSEY C., BUCK C. E., CHENG H., EDWARDS L., FRIEDRICH M., GROOTES P. M., GUILDERSON T.P., HAFLIDASON H., HAJDAS I., HATTÉ C., HEATON T., HOFFMANN D. L., HOGG A. G., HUGHEN K. A., KAISER K. F., KROMER B., MANNING S. W., NIU M., REIMER R. W., RICHARDS D. A. SCOTT E. M., SOUTHON J. R., STAFF R. A., TURNEY C. S. M., van der PLICHT J., "IntCal13 and Marine 13 Radiocarbon age calibration curves 0-50.000 years cal BP”. Radiocarbon 55(4), 2013, p. 1869-1887.

ROUSSOT-LARROQUE J. 2009 - Les complexes géométriques en Aquitaine In : El Mesolítico Geométrico en la Península Ibérica. Monografías Arqueológicas 44, pp. 279-306. 
ROZOY J. G. 1978 - Les derniers chasseurs. L'Epipaléolithique en France et en Belgique. Charleville, $\mathrm{n}^{\circ}$ spécial du Bulletin de la Société Archéologique Champenoise, 1257 p.

VALDEYRON N. 1994 - Le Sauveterrien : cultures et Sociétés mésolithiques dans la France du sud durant Le $X^{\circ}$ et le IX $X^{\circ}$ millénaire BP, Thèse de doctorat, Toulouse, Université Toulouse-II-Le-Mirail, 2 vol., $584 \mathrm{p}$.

\section{ABSTRACTS}

The excavation of a small area of a deep gallery within Rouffignac cave produced evidence for the exploitation of flint nodules accessible in the walls, ceiling and clayey fill of the cavity. A technological analysis of the lithic artifacts combined with refitting shed new light on the behavior of the groups who occupied the cave. The very homogeneous lithic assemblage demonstrates the on-site testing, roughing-out and sometimes reduction of nodules. No retouched blanks or hammerstones were recovered, and there is no evidence for any activity other than knapping. However, the technological characteristics of the assemblage and a radiocarbon date obtained on charcoal are consistent with the Mesolithic levels documented at the cave's porch (Barrière 1973a, b, 1974). Finally, a rapid survey of the floor of certain galleries shows the behavior documented in the studied area to be repeated feature of the cave's occupation.

\section{INDEX}

Keywords: Mesolithic, lithic technology, raw material exploitation, Rouffignac cave

\section{AUTHORS}

\section{MORGANE DACHARY}

Université Toulouse-Jean Jaurès, UMR 5608, TRACES, Maison de la recherche, 5 allée Antonio Machado, FR-31058 Toulouse cedex - morgane.dachary@orange.fr

\section{FRÉDÉRIC PLASSARD}

Université de Bordeaux, UMR 5199, PACEA, Allée geoffroy Saint-Hilaire, CS 50023, FR-33615

Pessac cedex - frederic.plassard@wanadoo.fr

\section{HÉLÈNE VALLADAS}

Laboratoire des Sciences du climat et de l'environnement LSCE/IPSL, CEA-CNRS-UVSQ, Avenue de la Terrasse, FR-91198 Gif-sur-Yvette cedex - helene.valladas@lsce.ipsl.fr 